ISSN 1678-3921

Journal homepage: www.embrapa.br/pab

For manuscript submission and journal contents, access: www.scielo.br/pab

\section{Behavior of dairy heifers after increasing the amounts of milk replacer powder added to whole milk}

\begin{abstract}
The objective of this work was to evaluate the effects of increasing the contents of total solids (TS) in whole milk, by adding increasing amounts of milk replacer powder, on the behavior of dairy heifers. Holstein-Gyr crossbred heifers $(n=60)$ were distributed in four treatments: 13.5, 16.1, 18.2, and 20.4\% TS. From 5 to 55 days of age, heifers received $6 \mathrm{~L}$ per day of liquid feed, which was reduced by half from 56 to 59 days. Heifers were weaned at 60 days of age and monitored until 90 days, and their behavior was evaluated weekly. During gradual weaning and after weaning, heifer behavior was recorded 1 hour before and 1 hour after liquid feed was offered, and, during weaning, it was evaluated by the scan method. Heifers fed liquid feed containing 20.4\% TS present a higher number of play behaviors, spent less time standing, and spent more time ruminating than those that received liquid feed with $13.5 \% \mathrm{TS}$, indicating that a higher nutritional plan during weaning is an effective strategy to reduce stress in this period.
\end{abstract}

Index terms: stress, vocalization, weaning.

\section{Comportamento de novilhas leiteiras após aumento da quantidade de sucedâneo do leite em pó adicionado ao leite integral}

Resumo - O objetivo deste trabalho foi avaliar os efeitos do aumento das concentrações de sólidos totais (ST) no leite, pela adição de quantidades crescentes de sucedâneo do leite em pó, sobre o comportamento de bezerras leiteiras. Bezerras mestiças Holandês-Gir $(\mathrm{n}=60)$ foram distribuídas em quatro tratamentos: 13,5, 16,1, 18,2 e 20,4\% de ST. Dos 5 aos 55 dias de idade, as bezerras receberam $6 \mathrm{~L}$ por dia de dieta líquida, que foi reduzida à metade dos 56 aos 59 dias. As bezerras foram desaleitadas aos 60 dias de idade e monitoradas até os 90 dias, e o seu comportamento foi avaliado semanalmente. Durante o desaleitamento gradual e após o desaleitamento, o comportamento das bezerras foi anotado 1 hora antes e 1 hora após o oferecimento da dieta liquida, e, durante a fase de desaleitamento, foi avaliado pelo método de varredura instantânea. As bezerras alimentadas com 20,4\% de ST na dieta líquida apresentam maior número de comportamentos de brincadeiras, menor tempo de permanência em pé e maior tempo ruminando, em comparação às que receberam $13,5 \%$ de ST na dieta líquida, o que indica que maior plano nutricional durante o desaleitamento é uma estratégia efetiva para a redução do estresse nessa etapa.

Termos para indexação: estresse, vocalização, desaleitamento. 


\section{Introduction}

A restricted volume of milk (4 L per day) and weaning dairy calves at 60 days of age are strategies used to reduce the costs of rearing heifers, besides promoting starter consumption and rumen development. However, calves fed a restrict diet show hunger-related behaviors, such as longer periods standing (De Paula Vieira et al., 2008) and a higher number of vocalizations (Thomas et al., 2001), compared with those consuming larger volumes of liquid feed. Calves that receive larger amounts of liquid feed also show a higher frequency of play behaviors, suggesting that a higher nutrient intake via liquid feed may improve welfare during the preand postweaning periods (Krachun et al., 2010; Jensen et al., 2015).

Despite the benefits of higher quantities of liquid feed to the average daily gain of calves (Kmicikewycz et al., 2013; Silper et al., 2014), without negatively affecting their health (Borderas et al., 2009; Bach et al., 2013) and rumen development (Khan et al., 2007), producers and technicians are opposed to elevating the volume of this type of feed due to increases in the costs of milk or milk replacer and to the reduction in starter consumption during the preweaning period (MillerCushon et al., 2013; Kiezebrink et al., 2015; Silva et al., 2015). Moreover, calves with a lower birth body weight, as Holstein-Gyr crossbreds and small-sized breeds, have a lower ability to ingest larger volumes of milk in two meals (Silper et al., 2014; Kiezebrink et al., 2015).

Although milk is the most complete and nutritious feed for calves, it is more expensive than milk replacer and its use increases the chances of fluctuations in the composition of total solids (TS), especially when waste milk is used. According to Glosson et al. (2015), the addition of "balancing" products to increase TS contents in liquid feed, without increasing the volume provided to calves, may be an interesting strategy to improve the nutritional status of the animals during the preweaning period. However, there are no known studies evaluating the behavior of dairy calves fed using this strategy.

The objective of this work was to evaluate the effects of increasing the contents of TS in whole milk, by adding increasing amounts of milk replacer power, on the behavior of dairy heifers.

\section{Materials and Methods}

All animal care and handling procedures were approved by the ethics committee of Embrapa Gado de Leite (protocol no. 06/2014). The experiment was conducted at the experimental farm of Embrapa Gado de Leite, located in the municipality of Coronel Pacheco, in the state of Minas Gerais, Brazil (21 $\left.{ }^{\circ} 33^{\prime} 22^{\prime \prime} \mathrm{S}, 43^{\circ} 06^{\prime} 15^{\prime \prime} \mathrm{W}\right)$.

Holstein-Gyr crossbred heifers $(n=60)$ were used, with a genetic composition $5 / 8$ or more Holstein and $3 / 8$ or less Gyr. These heifers were previously studied by Azevedo et al. (2016), from 5 to 89 days of age, regarding how feed intake, animal performance, and health scores were affected by increasing TS contents in whole milk through the addition of milk replacer power (MRP). Therefore, detailed descriptions of the used facilities, initial animal care, and nutritional composition of the diets from preweaning ( 5 to 59 days of age) to early postweaning (60 to 89 days of age) can be found in Azevedo et al. (2016).

Animals were distributed randomly into four treatments after birth, with different TS contents. Preweaning treatments consisted of increasing the amounts of MRP (Sprayfo Violet SSP, Trouw Nutrition Sloten, Deventer, Netherlands) added to whole milk, starting at $12.6 \pm 0.7 \% \mathrm{TS}($ mean $\pm \mathrm{SD})$ (Table 1), which was adjusted to the expected contents of $12.5 \%$ (actual TS $=13.5 \pm 0.53 \% ; \mathrm{n}=15), 15.0 \%$ (actual TS $=$ $16.1 \pm 0.03 \% ; \mathrm{n}=15), 17.5 \%$ (actual TS $=18.2 \pm 0.14 \%$; $\mathrm{n}=13$ ), and $20.0 \%$ (actual TS $=20.4 \pm 0.24 \% ; \mathrm{n}=15$ ). It should be noted that MRP was added to whole milk immediately before it was supplied to the heifers. The total volume of the treatment, of $6 \mathrm{~L}$ per day, was divided into two equal meals, which were offered in buckets, at 8:00 a.m. and 4:00 p.m., to heifers from 5 to 55 days of age. At 56 days of age, the total volume of liquid feed was reduced by half, i.e., to $3 \mathrm{~L}$ per day, being provided only at 08:00 a.m., and heifers were weaned at 60 days of age. During the preweaning period, 20\% flocculated starter (Soylac Rumen, Total Alimentos, Três Corações, MG, Brazil) and water were offered ad libitum. At 70 days of age, corn (Zea mays L.) silage was included in the diet, in a separate bucket, and was also offered ad libitum.

Heifers were restrained with a collar and a $1.8-\mathrm{m}$ chain attached to individual hutches $(1.5 \mathrm{~m}$ long $\times$ $0.90 \mathrm{~m}$ wide $\times 1.15 \mathrm{~m}$ high) made of rebar, with steel roofing, over a tropical grass pasture (Cynodon sp.).

Pesq. agropec. bras., Brasília, v.54, e00181, 2019

DOI: 10.1590/S1678-3921.pab2019.v54.00181 
The chain allowed the heifers free access to inside and outside the hutch. The hutches were on average $2.0 \mathrm{~m}$ apart to minimize contact between heifers. It should be pointed that all heifers were dehorned in the first week after weaning. Furthermore, one heifer subjected to the treatment with $17.5 \%$ TS was removed from the study in the last week of the postweaning period due to an accident that led to the fracture of its anterior right leg.

Sixty animals ( $\mathrm{n}=15$ per group) were evaluated weekly, from week 2 to 13 , from 8:00 a.m. to 5:00 p.m. Evaluations during weaning, from 56 to 59 days of age, and on the day of weaning, at 60 days of age, on week 15 , were performed 1 hour before and 1 hour after the time previously set for the supply of the afternoon liquid feed, which was from 3:00 p.m. to 5:00 p.m., using 36 animals ( $n=9$ per group). The number of play behaviors, vocalizations, sucks to hutch or utensils, licks to the hutch or utensils, self-licks, visits to the water bucket, urinations, and defecations were observed continuously by one trained observer for every ten heifers and recorded whenever externalized, considering frequency of occurrence; however, if the same activity was repeated within $1 \mathrm{~min}$, it was noted down only once. During gradual weaning and at weaning, the scan sampling method (Martin \& Bateson, 2007) was adopted, with 1-min intervals between evaluations and one trained observer for every five heifers, to check the times spent standing, lying, inside the hutch, outside the hutch, eating forage, visiting the silage trough, visiting the starter trough, ruminating, and idle (Table 1).

Statistical analyses were performed using the procedures of the SAS software, version 9.0 (SAS Institute Inc., Cary, NC, USA) and of the InStat software (GraphPad Software, San Diego, CA, USA). A completely randomized design with repeated measures over time was adopted for the behaviors evaluated by frequency of occurrence using the scan sampling method, during gradual weaning, between week 2 and 13 , and at weaning, on week 15 . Variables that did not show normality and did not reach this condition after transformation were subjected to the nonparametric analysis by the Kruskal-Wallis and Friedman tests for

Table 1. Ethogram of the evaluated behavior activities.

\begin{tabular}{|c|c|}
\hline Behavior & Description \\
\hline \multicolumn{2}{|c|}{ Behavior evaluated by frequency of occurrence } \\
\hline Play & Running, galloping, bucking, or jumping \\
\hline Vocalization & Emitting a sound \\
\hline Sucking hutch or utensils & Sucking at hutch structure or at starter/water buckets \\
\hline Licking hutch or utensils & Licking hutch structure or starter/water buckets continuously \\
\hline Self-licking & Licking own body continuously while standing or lying \\
\hline Visiting water bucket & Placing head inside the water bucket located inside the hutch \\
\hline Urination & Urinating inside or outside the hutch \\
\hline Defecation & Defecating inside or outside the hutch \\
\hline \multicolumn{2}{|c|}{ Behavior evaluated by the scan sampling method } \\
\hline Standing & Supported by the four limbs, inside or outside the hutch \\
\hline Lying & In lateral or sternal recumbency, inside or outside the hutch \\
\hline Remaining inside hutch & Inside the hutch, standing or lying \\
\hline Remaining outside hutch & Outside the hutch, standing or lying \\
\hline Eating forage & Eating forage inside or outside the hutch \\
\hline Visiting silage trough & $\begin{array}{l}\text { Placing head inside the silage trough located outside the hutch and displaying chewing movements } \\
\text { suggesting silage ingestion }\end{array}$ \\
\hline Visiting starter trough & $\begin{array}{l}\text { Placing head inside the trough located inside the hutch and displaying chewing movements suggesting } \\
\text { starter ingestion }\end{array}$ \\
\hline Rumination & Displaying repeated chewing movements after the return of the cud \\
\hline Idleness & Not ruminating at the moment of evaluation \\
\hline
\end{tabular}


comparison between weeks and between treatments, respectively, both at 5\% probability. All variables assessed by frequency of occurrence, during and on the day of weaning, were subjected to the nonparametric analysis of variance, and means were compared by Dunn's multiple comparison test, at 5\% probability. The variables visiting the starter trough and times spent standing, lying, and idle, evaluated during and on the day of weaning, showed normality and were subjected to the parametric analysis of variance, and means were compared by Tukey's test, at $5 \%$ probability.

\section{Results and Discussion}

Even though the calves were reared individually in a hutch, they showed play behaviors; however, the increasing contents of TS in liquid feed did not change the number of these activities between week 2 and 13, during preweaning (Table 2), indicating, that, under the conditions of this experiment, these behaviors were not only associated with nutrient intake. Krachun et al. (2010) found that calves housed in groups and fed 12 L per day of milk spent more time playing than those receiving $6 \mathrm{~L}$ per day, suggesting that this behavior may be a useful parameter for the evaluation of the satiety and welfare of calves. This result differs from that of the present study, in which heifers were housed in individual hutches and restrained with a collar and chain, with limited space for play behaviors, which might have influenced the response to this parameter, explaining the similarity among the assessed treatments.

Heifers that consumed $13.5 \%$ TS vocalized more times $(\mathrm{p}=0.02)$ than those fed $18.2 \% \mathrm{TS}$, probably due to the lower nutritional input provided to the animals subjected to the first treatment, and intermediate values were observed for 16.1 and $20.4 \%$ TS. Thomas et al. (2001) found a greater number of vocalizations by calves consuming $5 \mathrm{~L}$ per day of milk than $8 \mathrm{~L}$ per day, showing that the supplied feed may affect this variable. However, in the present study, the number of vocalizations by heifers that received $13.5 \% \mathrm{TS}$ in liquid feed did not differ from that of the group that consumed 16.1 and $20.4 \%$ TS, indicating that, in addition to nutrition, other factors are also associated with the increase in vocalizations in dairy calves.

The number of licks to the hutch or utensils by the heifers fed liquid feed containing 20.4\% TS was higher $(\mathrm{p}=0.01)$ than that of the animals that consumed $16.1 \% \mathrm{TS}$, and intermediate values were observed for the treatments containing 13.5 and $18.25 \%$ TS. The number of self-licks was higher in heifers fed $20.4 \%$ TS $(\mathrm{p}=0.01)$ than in those receiving 13.5 and $18.2 \% \mathrm{TS}$, and an intermediate value was found for the animals that consumed $16.1 \%$ TS. The stereotypic behaviors of sucking and licking the hutch or utensils, as well as of self-licking, were recorded in all treatments. Heifers fed $20.4 \%$ TS showed more licks to the hutch or utensils and self-licks than the animals receiving lower contents of TS, which was an unexpected finding, since the higher occurrence of these stereotypic behaviors is

Table 2. Mean values for number of play activities (PLY), vocalizations (VOC), sucks to hutch or utensils (SHU), licks to the hutch or utensils (LHU), self-licks (SLI), visits to the water bucket (VWB), urinations (URI), and defecations (DEF) by dairy heifers fed liquid feed with different total solids contents between week 2 and 13 of age ${ }^{(1)}$.

\begin{tabular}{|c|c|c|c|c|c|c|c|}
\hline \multirow[t]{2}{*}{ Behavior } & \multicolumn{4}{|c|}{ Treatments (percentage of total solids in whole milk) } & \multirow[t]{2}{*}{$\mathrm{SEM}^{(2)}$} & \multicolumn{2}{|c|}{ p-value } \\
\hline & 13.5 & 16.1 & 18.2 & 20.4 & & Treatment & Weeks \\
\hline PLY & 2.6 & 2.5 & 2.8 & 2.7 & 0.10 & 0.88 & 0.01 \\
\hline VOC & $7.7 \mathrm{~A}$ & $6.0 \mathrm{AB}$ & $5.2 \mathrm{~B}$ & 7.0AB & 0.51 & 0.02 & 0.01 \\
\hline SHU & 3.4 & 2.5 & 1.9 & 2.7 & 0.10 & 0.08 & 0.01 \\
\hline LHU & $9.2 \mathrm{AB}$ & $7.3 \mathrm{~B}$ & 8.9AB & $9.4 \mathrm{~A}$ & 0.32 & 0.01 & 0.01 \\
\hline SLI & 25.9B & $26.6 \mathrm{AB}$ & $24.2 \mathrm{~B}$ & $31.5 \mathrm{~A}$ & 0.65 & 0.01 & 0.01 \\
\hline VWB & 3.7 & 3.5 & 3.8 & 3.7 & 0.17 & 0.27 & 0.01 \\
\hline URI & 3.4 & 3.0 & 3.4 & 3.2 & 0.08 & 0.21 & 0.01 \\
\hline DEF & $1.9 \mathrm{~B}$ & $2.4 \mathrm{~A}$ & $2.1 \mathrm{AB}$ & $2.3 \mathrm{~A}$ & 0.06 & 0.01 & 0.01 \\
\hline
\end{tabular}

${ }^{(1)}$ Means followed by different letters, in the rows, differ by Dunn's multiple comparison test, at $5 \%$ probability. ${ }^{(2)}$ Standard error of the mean. 
usually associated with diets with restricted amounts of milk and, consequently, with insufficient satiety (De Paula Vieira et al., 2008). Therefore, nutrition is probably not the only factor responsible for the change in the behavior of dairy calves, which may justify the differences observed between treatments.

Heifers fed $20.4 \%$ TS defecated more times than those that received liquid feed with $13.5 \% \mathrm{TS}(\mathrm{p}=0.01)$. Azevedo et al. (2016), working with the same animals of this experiment, reported dry matter intake, as percentage of body weight, of 1.7, 1.9, 2.0, and 2.0 for heifers fed 13.5, 16.1, 18.2, and 20.4\% TS ( $\mathrm{p}<0.01)$. This justifies the higher number of defecations observed for the heifers subjected to the treatment with $20.4 \% \mathrm{TS}$, compared with those fed $13.5 \%$ TS.

Independently of the TS contents in liquid feed, a higher number of play activities was observed up to week 8 (Table 3). However, in week 9, when the heifers were weaned, this behavior declined, and the number of vocalizations and visits to the water bucket increased (Table 3). These behavioral changes were associated with the stress caused by the reduction of $50 \%$ in the volume of the liquid diet offered during gradual weaning, causing discomfort in the animals in this period. It is important to observe that, regardless of the increased content of TS, there was an increase in the number of vocalizations in response to weaning stress in week 9, indicating that non-nutritional factors possibly also interfere with vocalization behavior. These factors, which include satiety mediated partially by gut fill (Allen, 1996) and metabolites and hormones provided by milk metabolism, affect satiety and the behavior of calves (Ingvartsen \& Andersen, 2000; Jasper et al., 2008).

In this experiment, the number of visits to the water bucket increased from week 9 onwards (Table 3), possibly due to the reduction of $50 \%$ in liquid feed during weaning, and was lower for the treatment with 20.4\% TS. Likewise, Guindon et al. (2015) found greater water intake in the preweaning period, from 1 to 6 six weeks of age, but in calves fed liquid feed containing higher contents of TS.

Treatments had no effect on the number of vocalizations, sucks to hutch or utensils, licks to the hutch or utensils, self-licks, urinations, and defecations during the weaning period (Table 4). Heifers that consumed liquid feed with lower contents of TS were expected to perform a greater number of vocalizations and stereotypical behaviors; however, there was no difference between treatments for these characteristics,

Table 3. Mean values for number of play activities (PLY), vocalizations (VOC), sucks to hutch or utensils (SHU), licks to the hutch or utensils (LHU), self-licks (SLI), visits to the water bucket (VWB), urinations (URI), and defecations (DEF) by dairy heifers fed liquid feed with different total solids contents between week 2 and 13 of age, according to the evaluated week $^{(1)}$.

\begin{tabular}{lcccccccc}
\hline \multirow{2}{*}{ Week } & \multicolumn{7}{c}{ Behavior } \\
\cline { 2 - 9 } & PLY & VOC & SHU & LHU & SLI & VWB & URI & DEF \\
\hline 2 & $3.6 \mathrm{AB}$ & $6.3 \mathrm{~B}$ & $0.7 \mathrm{~B}$ & $5.5 \mathrm{~B}$ & $17.9 \mathrm{C}$ & $2.8 \mathrm{BC}$ & $2.0 \mathrm{C}$ & $2.8 \mathrm{AB}$ \\
3 & $5.8 \mathrm{~A}$ & $10.4 \mathrm{AB}$ & $2.5 \mathrm{AB}$ & $7.5 \mathrm{~B}$ & $25.7 \mathrm{~B}$ & $3.3 \mathrm{BC}$ & $3.0 \mathrm{~B}$ & $1.8 \mathrm{BC}$ \\
4 & $5.1 \mathrm{~A}$ & $6.5 \mathrm{~B}$ & $3.9 \mathrm{AB}$ & $6.9 \mathrm{~B}$ & $27.7 \mathrm{AB}$ & $2.1 \mathrm{C}$ & $3.4 \mathrm{AB}$ & $1.7 \mathrm{C}$ \\
5 & $4.6 \mathrm{AB}$ & $6.6 \mathrm{~B}$ & $3.4 \mathrm{AB}$ & $8.7 \mathrm{AB}$ & $28.0 \mathrm{AB}$ & $2.3 \mathrm{C}$ & $3.5 \mathrm{AB}$ & $1.8 \mathrm{C}$ \\
6 & $3.8 \mathrm{AB}$ & $5.6 \mathrm{~B}$ & $3.6 \mathrm{AB}$ & $12.0 \mathrm{~A}$ & $28.0 \mathrm{AB}$ & $3.4 \mathrm{BC}$ & $3.7 \mathrm{AB}$ & $1.7 \mathrm{C}$ \\
7 & $3.8 \mathrm{AB}$ & $5.9 \mathrm{~B}$ & $4.1 \mathrm{~A}$ & $11.6 \mathrm{~A}$ & $34.5 \mathrm{~A}$ & $3.2 \mathrm{BC}$ & $3.4 \mathrm{AB}$ & $1.6 \mathrm{C}$ \\
8 & $2.1 \mathrm{BC}$ & $10.1 \mathrm{AB}$ & $4.6 \mathrm{~A}$ & $12.3 \mathrm{~A}$ & $35.0 \mathrm{~A}$ & $2.9 \mathrm{BC}$ & $3.3 \mathrm{~B}$ & $1.6 \mathrm{C}$ \\
9 & $0.5 \mathrm{D}$ & $21.0 \mathrm{~A}$ & $2.1 \mathrm{AB}$ & $12.6 \mathrm{~A}$ & $33.2 \mathrm{AB}$ & $4.1 \mathrm{AB}$ & $2.6 \mathrm{BC}$ & $2.2 \mathrm{AB}$ \\
10 & $0.4 \mathrm{D}$ & $1.7 \mathrm{BC}$ & $3.2 \mathrm{AB}$ & $9.7 \mathrm{AB}$ & $24.3 \mathrm{BC}$ & $4.9 \mathrm{~A}$ & $2.4 \mathrm{BC}$ & $2.3 \mathrm{AB}$ \\
11 & $0.9 \mathrm{CD}$ & $0.5 \mathrm{C}$ & $1.6 \mathrm{~B}$ & $6.1 \mathrm{~B}$ & $22.3 \mathrm{BC}$ & $4.8 \mathrm{AB}$ & $3.2 \mathrm{~B}$ & $2.8 \mathrm{~A}$ \\
12 & $0.5 \mathrm{D}$ & $0.4 \mathrm{C}$ & $1.1 \mathrm{~B}$ & $4.6 \mathrm{~B}$ & $22.2 \mathrm{BC}$ & $5.4 \mathrm{~A}$ & $4.0 \mathrm{AB}$ & $2.7 \mathrm{AB}$ \\
13 & $0.9 \mathrm{CD}$ & $0.6 \mathrm{C}$ & $0.5 \mathrm{~B}$ & $6.5 \mathrm{~B}$ & $26.2 \mathrm{~B}$ & $5.0 \mathrm{~A}$ & $4.5 \mathrm{~A}$ & $3.1 \mathrm{~A}$ \\
\hline
\end{tabular}

(1)Means followed by different letters, in the rows, differ by Dunn's multiple comparison test, at $5 \%$ probability. 
possibly due to the supplied volume of liquid feed $(6 \mathrm{~L}$ per day).

The number of play behaviors performed during gradual weaning was low in all treatments, showing the discomfort of the animals during this period. However, with $20.4 \%$ TS in liquid feed, a higher number of play behaviors and a smaller number of visits to the water buckets were observed, compared with 13.5\% TS (Table 4). According to Krachun et al. (2010), play behaviors are indicative of welfare; therefore, it is suggested that heifers receiving higher TS contents in liquid feed possibly support the weaning period better than those fed the other amounts evaluated.

There was no effect of TS contents in liquid feed on the time spent inside the hutch, outside the hutch, consuming forage, visiting the starter trough, or idle (Table 5). Heifers from the treatment with $13.5 \% \mathrm{TS}$ stood longer than those that consumed 18.2 and $20.4 \%$ TS, showing their discomfort when receiving liquid feed with lower TS contents. De Paula Vieira et al. (2008) also reported longer standing periods for calves that consumed restricted amounts of liquid feed, when

Table 4. Mean values for number of play activities (PLY), vocalizations (VOC), sucks to hutch or utensils (SHU), licks to the hutch or utensils (LHU), self-licks (SLI), visits to the water bucket (VWB), urinations (URI), and defecations (DEF) during the weaning of dairy heifers fed liquid feed with different total solids contents ${ }^{(1)}$.

\begin{tabular}{|c|c|c|c|c|c|c|c|}
\hline \multirow[t]{2}{*}{ Behavior } & \multicolumn{4}{|c|}{ Treatments (percentage of total solids in whole milk) } & \multirow[t]{2}{*}{$\mathrm{SEM}^{(2)}$} & \multicolumn{2}{|c|}{ p-value } \\
\hline & 13.5 & 16.1 & 18.2 & 20.4 & & Treatment & Weeks \\
\hline PLY & $0.02 \mathrm{~B}$ & $0.1 \mathrm{AB}$ & $0.1 \mathrm{AB}$ & $0.5 \mathrm{~A}$ & 0.07 & 0.01 & 0.11 \\
\hline VOC & 6.6 & 11.1 & 7.5 & 8.7 & 0.45 & 0.35 & 0.01 \\
\hline SHU & 0.8 & 1.1 & 0.5 & 1.2 & 0.06 & 0.10 & 0.10 \\
\hline LHU & 2.6 & 2.5 & 2.0 & 3.1 & 0.39 & 0.46 & 0.62 \\
\hline SLI & 9.0 & 11.4 & 7.6 & 10.7 & 0.71 & 0.09 & 0.45 \\
\hline VWB & $2.0 \mathrm{~A}$ & $1.4 \mathrm{~A}$ & $1.3 \mathrm{~A}$ & $0.6 \mathrm{~B}$ & 0.19 & 0.01 & 0.05 \\
\hline URI & 1.0 & 0.9 & 1.1 & 1.2 & 0.06 & 0.41 & 0.18 \\
\hline DEF & 0.4 & 0.4 & 0.4 & 0.4 & 0.02 & 0.93 & 0.80 \\
\hline
\end{tabular}

${ }^{(1)}$ Means followed by different letters, in the rows, differ by Dunn's multiple comparison test, at $5 \%$ probability. ${ }^{(2)}$ Standard error of the mean.

Table 5. Scan average duration (min) for the behaviors termed standing (STD), lying (LYI), inside the hutch (INT), outside the hutch (EXT), eating forage (FOR), visiting the starter trough (STA), idle (IDL), and rumination (RUM) during the weaning of dairy heifers fed liquid feed with different total solids contents ${ }^{(1)}$.

\begin{tabular}{|c|c|c|c|c|c|c|c|c|}
\hline \multirow[t]{2}{*}{ Behavior } & \multicolumn{4}{|c|}{ Treatments (percentage of total solids in whole milk) } & \multirow[t]{2}{*}{$\mathrm{SEM}^{(2)}$} & \multicolumn{3}{|c|}{ p-value ${ }^{(3)}$} \\
\hline & 13.5 & 16.1 & 18.2 & 20.4 & & $\mathrm{~T}$ & W & $\mathrm{T} \times \mathrm{W}$ \\
\hline $\operatorname{STD}^{(2)}$ & $83.0 \mathrm{~A}$ & 79.7AB & $67.9 \mathrm{BC}$ & $63.7 \mathrm{C}$ & 2.32 & 0.02 & 0.09 & 0.20 \\
\hline $\operatorname{LYI}^{(3)}$ & $37.0 \mathrm{C}$ & $40.3 \mathrm{BC}$ & $52.1 \mathrm{AB}$ & $56.3 \mathrm{~A}$ & 1.60 & 0.02 & 0.09 & 0.20 \\
\hline INT & 21.7 & 23.4 & 20.5 & 20.4 & 1.10 & 0.87 & 0.01 & 0.81 \\
\hline $\mathrm{EXT}^{(4)}$ & 98.3 & 96.6 & 99.5 & 99.6 & 3.65 & 0.42 & 0.01 & - \\
\hline FOR & 25.8 & 19.6 & 18.5 & 14.3 & 1.19 & 0.20 & 0.35 & 0.15 \\
\hline STA & 6.2 & 6.2 & 5.7 & 5.5 & 0.92 & 0.88 & 0.01 & 0.13 \\
\hline IDL & 82.2 & 87.1 & 87.6 & 88.0 & 2.36 & 0.76 & 0.32 & 0.26 \\
\hline $\operatorname{RUM}^{(4)}$ & $5.8 \mathrm{~B}$ & $7.1 \mathrm{~B}$ & $8.2 \mathrm{AB}$ & $12.2 \mathrm{~A}$ & 0.89 & 0.01 & 0.14 & - \\
\hline
\end{tabular}

${ }^{(1)}$ Means followed by different letters, in the rows, differ between treatments by Tukey's test, at $5 \%$ probability. ${ }^{(2)}$ Standard error of the mean.

${ }^{(3)} \mathrm{T}$, treatment effect; W, week effect; and $\mathrm{T} x \mathrm{~W}$, treatment by week interaction. 
compared with those fed ad libitum. Heifers receiving $20.4 \%$ TS spent less time standing and more time lying and at rumination than those fed diets containing 13.5 and $16.1 \%$ TS in liquid feed, showing less weaning stress.

During the days of weaning, from 56 to 60 days (Table 6), the number of vocalizations changed. The lowest number of vocalizations was recorded at 56 days of age; and intermediate ones were found at 57 , 58 , and 59 days. On the day of weaning, at 60 days of age, the supply of liquid feed to the heifers was interrupted and the largest number of vocalizations was observed. These results confirm the occurrence of anguish-related behaviors during weaning (Jasper et al., 2008; Weary et al., 2008). Another factor that might have aggravated stress at weaning is the fact that preweaning heifers were reared in the same location as the already-weaned ones, being subjected to the same stimuli to feeding caused by the presence of the keeper, visualization, and noise of the buckets. Jasper et al. (2008) and Thomas et al. (2001) reported that vocalizations are concentrated soon after weaning when other calves are being fed.

The day of weaning affected the times spent inside the hutch, visiting the starter trough, and outside the hutch, which may be attributed to the location of the starter trough inside the hutch. Heifers spent more time inside the hutch at 60 days of age, but remained longer outside at 56 days than at 58,59, and 60 days of age.

At 60 days of age, heifers also paid longer visits (8.3 min) to the starter trough than at 56 and 57 days of age (3.2 and $5.2 \mathrm{~min}$, respectively), which may be

Table 6. Mean time (min) of behavior inside the hutch (INT), visiting the starter trough (STA), and outside the hutch (EXT), as well as number of vocalizations (VOC), during the weaning of dairy heifers fed liquid feed with different total solids contents.

\begin{tabular}{lccccc}
\hline Behavior & \multicolumn{5}{c}{ Days } \\
\cline { 2 - 6 } & 56 days & 57 days & 58 days & 59 days & 60 days \\
\hline INT $^{(1)}$ & $14.1 \pm 8.7 \mathrm{C}$ & $18.4 \pm 11.5 \mathrm{BC}$ & $21.4 \pm 12.3 \mathrm{~B}$ & $22.8 \pm 17.5 \mathrm{~B}$ & $32.0 \pm 21.4 \mathrm{~A}$ \\
$\mathrm{STA}^{(1)}$ & $3.2 \pm 3.1 \mathrm{C}$ & $5.2 \pm 3.6 \mathrm{~B}$ & $6.6 \pm 4.7 \mathrm{AB}$ & $6.3 \pm 4.3 \mathrm{AB}$ & $8.3 \pm 5.4 \mathrm{~A}$ \\
$\mathrm{EXT}^{(2)}$ & $1.8 \mathrm{~A}$ & $1.7 \mathrm{AB}$ & $1.7 \mathrm{BC}$ & $1.6 \mathrm{BC}$ & $1.5 \mathrm{C}$ \\
$\mathrm{VOC}^{(2)}$ & $5.6 \mathrm{C}$ & $11.2 \mathrm{~B}$ & $7.1 \mathrm{~B}$ & $5.9 \mathrm{~B}$ & $12.5 \mathrm{~A}$ \\
\hline
\end{tabular}

(1)Means followed by different letters, in the rows, differ by Tukey's test, at $5 \%$ probability. ${ }^{(2)}$ Means followed by different letters, in the rows, differ by Dunn's multiple comparison test by $5 \%$ probability. attributed to the increased starter intake after liquid feed was interrupted (Azevedo et al., 2016), and they spent more time inside the hutches than when they started receiving half of the amount of liquid feed during the morning, at 56 days of age.

Heifers fed $20.4 \%$ TS ruminated longer (Table 5) than those receiving 13.5 and $16.1 \%$ TS. The lack of rumination may occur in situations of discomfort and stress, suggesting that the greater nutritional input during the preweaning period, provided by liquid feed in the treatments with higher TS contents, influenced rumination time.

\section{Conclusion}

Increasing total solids (TS) in whole milk by adding milk replacer powder with $20.4 \%$ TS reduces behaviors related to heifer stress during the preweaning and weaning periods.

\section{Acknowledgments}

To Conselho Nacional de Desenvolvimento Científico e Tecnológico (CNPq), for financial support (process no. 448443/2014-7).

\section{References}

ALLEN, M.S. Physical constraints on voluntary intake of forages by ruminants. Journal Animal Science, v.74, p.3063-3075, 1996. DOI: https://doi.org/10.2527/1996.74123063x.

AZEVEDO, R.A.; MACHADO, F.S.; CAMPOS, M.M.; FURINI, P.M.; RUFINO, S.R.A.; PEREIRA, L.G.R.; TOMICH T.R.; COELHO, S.G. The effects of increasing amounts of milk replacer powder added to whole milk on feed intake and performance in dairy heifers. Journal of Dairy Science, v.99, p.8018-8027, 2016. DOI: https://doi.org/10.3168/jds.2015-10457.

BACH, A.; TERRÉ, M.; PINTO, A. Performance and health responses of dairy calves offered different milk replacer allowances. Journal of Dairy Science, v.96, p.7790-7797, 2013. DOI: http://doi.org/10.3168/jds.2013-6909.

BORDERAS, T.F.; DE PASSILLÉ, A.M.B.; RUSHEN, J. Feeding behavior of calves fed small or large amounts of milk. Journal of Dairy Science, v.92, p.2843-2852, 2009. DOI: https://doi.org/10.3168/jds.2008-1886.

DE PAULA VIEIRA, A.; GUESDON, V.; DE PASSILLÉ, A.M.; VON KEYSERLINGK, M.A.G.; WEARY, D.M. Behavioural indicators of hunger in dairy calves. Applied Animal Behaviour Science, v.109, p.180-189, 2008. DOI: http://doi:10.1016/j. applanim.2007.03.006. 
GLOSSON, K.M.; HOPKINS, B.A.; WASHBURN, S.P.; DAVIDSON, S.; SMITH, G.; EARLEYWINE, T.; MA, C. Effect of supplementing pasteurized milk balancer products to heat-treated whole milk on the growth and health of dairy calves. Journal of Dairy Science, v.98, p.1127-1135, 2015. DOI: https://doi.org/10.3168/jds.2014-8567.

GUINDON, N.E.; ANTAYA, N.T.; CABRAL, R.G.; WHITEHOUSE, N.L.; EARLEYWINE, T.J.; ERICKSON, P.S. Effects of human visitation on calf growth and performance of calves fed different milk replacer feeding levels. Journal of Dairy Science, v.98, p.8952-8961, 2015. DOI: https://doi.org/10.3168/ jds.2015-9759.

INGVARTSEN, K.L.; ANDERSEN, J.B. Integration of metabolism and intake regulation: a review focusing on periparturient animals. Journal of Dairy Science, v.83, p.1573-1597, 2000. DOI: https:// doi.org/10.3168/jds.S0022-0302(00)75029-6.

JASPER, J.; BUDZYNSKA, M.; WEARY, D.M. Weaning distress in dairy calves: acute behavioural responses by limit-fed calves. Applied Animal Behaviour Science, v.110, p.136-143, 2008. DOI: https://doi.org/10.1016/j.applanim.2007.03.07.

JENSEN, M.B.; DUVE, L.R.; WEARY, D.M. Pair housing and enhanced milk allowance increase play behavior and improve performance in dairy calves. Journal of Dairy Science, v.98, p.2568-2575, 2015. DOI: https://doi.org/10.3168/jds.2014-8272.

KHAN, M.A.; LEE, H.J.; LEE, W.S.; KIM, H.S.; KI, K.S.; HUR, T.Y.; SUH, G.H.; KANG, S.J.; CHOI, Y.J. Structural growth, rumen development, and metabolic and immune responses of Holstein male calves fed milk through step-down and conventional methods. Journal of Dairy Science, v.90, p.3376-3387, 2007. DOI: https://doi.org/10.3168/jds.2007-0104.

KIEZEBRINK, D.J.; EDWARDS, A.M.; WRIGHT, T.C.; CANT, J.P.; OSBORNE, V.R. Effect of enhanced whole-milk feeding in calves on subsequent first-lactation performance. Journal of Dairy Science, v.98, p.349-356, 2015. DOI: https://doi.org/10.3168/ jds.2014-7959.
KMICIKEWYCZ, A.D.; SILVA, D.N.L. da; LINN, J.G.; LITHERLAND, N.B. Effects of milk replacer program fed 2 or 4 times daily on nutrient intake and calf growth. Journal of Dairy Science, v.96, p.1125-1134, 2013. DOI: https://doi.org/10.3168/ jds.2012-5738.

KRACHUN, C.; RUSHEN, J.; DE PASSILlÉ, A.M. Play behaviour in dairy calves is reduced by weaning and by a low energy intake. Applied Animal Behaviour Science, v.122, p.7176, 2010. DOI: https://doi.org/10.1016/j.applanim.2009.12.002.

MARTIN, P.; BATESON, P. Measuring behavior: an introductory guide. Cambridge: University Press, 2007.

MILLER-CUSHON, E.K.; BERGERON, R.; LESLIE, K.E.; MASON, G.J.; DEVRIES, T.J. Effect of feed presentation on feeding patterns of dairy calves. Journal of Dairy Science, v.96, p.7260-7268, 2013. DOI: https://doi.org/10.3168/jds.2013-7013.

SILPER, B.F.; LANA, A.M.Q.; CARVALHO, A.U.; FERREIRA, C.S.; FRANZONI, A.P.S.; LIMA, J.A.M.; SATURNINO, H.M.; REIS, R.B.; COELHO, S.G. Effects of milk replacer feeding strategies on performance, ruminal development, and metabolism of dairy calves. Journal of Dairy Science, v.97, p.1016-1025, 2014. DOI: https://doi.org/10.3168/jds.2013-7201.

SILVA, A.L.; MARCONDES, MI.; DETMANN, E.; MACHADO, F.S.; VALADARES FILHO, S.C.; TRECE, A.S.; DIJKSTRA, J. Effects of raw milk and starter feed on intake and body composition of Holstein $\times$ Gyr male calves up to 64 days of age. Journal of Dairy Science, v.98, p.2641-2649, 2015. DOI: https://doi.org/10.3168/jds.2014-8833.

THOMAS, T.J.; WEARY, D.M; APPLEBY, M.C. Newborn and 5 -week-old calves vocalize in response to milk deprivation. Applied Animal Behaviour Science, v.74, p.165-173, 2001. DOI: https://doi.org/10.1016/S0168-1591(01)00164-2.

WEARY, D.M.; JASPER, J.; HÖTZEL, M.J. Understanding weaning distress. Applied Animal Behaviour Science, v.110, p.2441, 2008. DOI: https://doi.org/10.1016/j.applanim.2007.03.025.

Pesq. agropec. bras., Brasília, v.54, e00181, 2019

DOI: 10.1590/S1678-3921.pab2019.v54.00181 